УДК 631.1.342:631.526.3:351.777.6

(C) 2012

Москалець В. В., кандидат сільськогосподарських наук,

Лавров В. В., доктор сільськогосподарських наук,

Москалець Т. 3., кандидат біологічних наук

Білоцерківський національний аграрний університет

Москалець В. І., стариий науковий співробітник

Носівська селекційно-дослідна станція Інституту сільськогосподарської мікробіології

і агропромислового виробництва НААН України

Писаренко П. В., доктор сільськогосподарських наук, професор

Полтавська державна аграрна академія

\title{
СОРТ ТРИТИКАЛЕ ОЗИМОГО «СЛАВЕТНЕ»: ПОХОДЖЕННЯ, ЕКОЛОГІЧНА СТІЙКІСТЬ, АГРОБІОТИЧНИЙ ПОТЕНЦІАЛ, ВИХІДНИЙ МАТЕРІАЛ
}

Рецензент - доктор сільськогосподарських наук, академік НААН Украӥни А. П. Стадник

Викладено агробіологічну характеристику сорту тритикале озимого «Славетне», виведеного иляхом індивідуального відбору й виділеного з гібридної комбінації (Августо х Ягуар) х№ 1364/93 за кількісними (урожайність зерна, кількість і маса зерна з колоса, натура зерна, маса 1000 зерен) та якісними (вміст білка, «сирої» клейковини) параметрами урожаю зерна, за екологічною стійкістю до фітопатогенних збудників хвороб, аномалій зимово-весняного та літнього періодів, вилягання. На базі сорту «Славетне» иляхом індивідуального відбору створено більи морозостійку лінію «Славетне покращене». Доведено здатність тритикале озимого сорту “Славетне» забезпечувати на дерново-середньопідзолистому супішаному і дерново-підзолистому супіщаному легкосуглинковому трунтах східного та цеентрального Полісся, на чорноземі глибокому середньосуглинковому $і$ чорноземі типовому малогумусному легкосуглинковому північного та цеентрального Лісостепу Украӥни високу врожайність.

Ключові слова: тритикале озиме, сорт, екологічна стійкість, агробіотичний потенціал, стабільність продуктивності.

Постановка проблеми. Тритикале - це плід понад вікової копіткої роботи генетиків і селекціонерів, у якому поєднані властивості жита й пшениці [9]. За даними ФАО, основними виробниками зерна тритикале є Польща, Білорусь, Нiмеччина, Австралія, Франція, Китай, Угорщина та інші, де посівна площа тритикале становить близько 5 млн га [16]. В Україні під посівами тритикале зайнято близько 200 тис. га, у тому числі близько 80 тис. га - під тритикале ярим. Основні площі тритикале озимого та ярого (в межах 2-5 тис. га) сконцентровані у Волинсь- кій, Чернігівській, Сумській, Житомирській, Київській, Дніпропетровській, Донецькій, Харківській, Полтавській, Львівській областях [15].

Станом на 2010 р. до Державного реєстру сортів рослин, придатних для поширення в Україні, занесені 25 сортів тритикале озимого та 16 ярого. Щороку проходять державну експертизу десятки сортів тритикале вітчизняної та зарубіжної селекції. Проте ця культура ще досі не отримала належного виробничого використання. Ї̈̈ генетичний потенціал використовується на 40 \%. Основними причинами, що заважають поширенню тритикале озимого, $є$ складність поєднання в одному генотипі якостей продуктивності, екологічної стійкості, а також відсутність природного центру походження, де можна було би брати вихідний матеріал для селекції. Тому наразі актуальним залишається удосконалення методів селекції, проведення відбору потрібних якостей за різних природно-кліматичних умов та екологічне випробування перспективного вихідного матеріалу, сортів [14]. Для систематичного поліпшення сортів під час їх експертизи на відмінність, однорідність, стійкість необхідно враховувати вимоги екологічної безпеки, біологічні, морфологічні та фізіологічні властивості рослин. Це зумовлено необхідністю правового захисту сортів-оригінаторів. Отже, для ефективного використання зазначеного сорту потрібно продовжувати дослідження його властивостей у різних екологічних умовах із використанням прогресивних агротехнологій.

Аналіз основних досліджень і публікацій, у яких започатковано розв'язання проблеми. Виведення сортів, що поєднують високу врожайність із генетичною резистентністю до лімі- 
туючих факторів навколишнього природного середовища, шкідників і збудників хвороб конкретного регіону - найголовніша 3 центральних ланок в адаптивному землеробстві [3]. До сорту ставлять жорсткі вимоги, поскільки зростання виробництва зерна грунтується на селекційному поліпшенні сортів [5]. Вагомим важелем впливу на зростання врожайності зерна $є$ також розробка та впровадження науково обгрунтованої сортової агротехніки [1]. Різноманітність грунтовокліматичних умов зон сіяння тритикале зумовлює необхідність проводити добір екотипів із відповідними біолого-морфологічними властивостями [13], що дає можливість збільшити урожайність зерна до $30 \%$ [2].

Мета досліджень - дослідити морфологічні й біологічні властивості тритикале озимого сорту «Славетне» за прогресивних елементів агротехнології вирощування в умовах східного та центрального Полісся, північного і центрального Лісостепу.

Матеріали і методи досліджень. Дослідження 3 селекції тритикале проведено впродовж 1994-2005 pp. на стаціонарі Носівської селекційно-дослідної станції Інституту сільськогосподарської мікробіології та агропромислового виробництва НААН (Носівська СДС ІСГМіАПВ НААН), що в Чернігівській області. У 1994 р. для селекційних схрещувань був задіяний зимота морозостійкий вихідний матеріал тритикале 3 Устимівської ДС (Полтавська обл.): № 1318/93, № $1364 / 93$, із залученням каталожного зразка К-9844. Наприкінці 90-х рp. із гібридних популяцій Ягуар х № 1364/93, (Августо х Ягуар) х № 1364/93 і Августо х Ягуар було відібрано вихідний матеріал, який характеризувався високими показниками продуктивності, морозо- та зимостійкості (9 балів). Температура повітря в період їх виділення становила мінус $25-30{ }^{\circ} \mathrm{C}$ упродовж 8-10 діб, а грунту на глибині залягання вузла кущіння - мінус $20^{\circ} \mathrm{C}$. Відібрані екотипи тритикале озимого вивчали в селекційних розсадниках, розмножували кращі 3 них на насіння. В результаті селекції було виведено сорт тритикале озимого «Славетне», який у 2004 р. внесено до Реєстру сортів рослин України (авторське свідоцтво № 0489; автори: В. І. Москалець, В. В. Москалець, Г. П. Іллічов, М. Д. Горган).

Польові та лабораторні дослідження проводили згідно з загальноприйнятими методами [4, 10]. Дослідження агротехнології вирощування проведено впродовж 2006-2011 рр. на стаціонарі Носівської СДС ІСГМіАПВ НААН, навчальнонауковому дослідному центрі Білоцерківського національного аграрного університету (ННДЦ БНАУ), що в Київській обл., Інституту сільського господарства Полісся НААН (ІСГП НААН), що в с. Грозіно Коростенського р-ну Житомирської обл., Чернігівського інституту агропромислового комплексу НААН (назва до 2012 р.) (ЧІАПВ НААН), що в с. Прогрес Козелецького p-ну Чернігівської області. Схема дослідів включала 7 варіантів: 1 - контроль; $2-\mathrm{P}_{45} \mathrm{~K}_{45}$; $3-\mathrm{N}_{20} \mathrm{P}_{45} \mathrm{~K}_{45} ; 4-\mathrm{N}_{45} \mathrm{P}_{45} \mathrm{~K}_{45} ; 5-\mathrm{N}_{45} \mathrm{P}_{90} \mathrm{~K}_{90}$; 6 - $\mathrm{N}_{90} \mathrm{P}_{45} \mathrm{~K}_{45} ; 7-\mathrm{N}_{90} \mathrm{P}_{90} \mathrm{~K}_{90}$. Площа варіанту досліду складала $35 \mathrm{~m}^{2}$, облікова - $30 \mathrm{~m}^{2}$. Залежно від умов закладання досліду, попередниками для тритикале озимого були вико-вівсяна суміш, пелюшко-вівсяна суміш на зелену масу. Застосовували загальноприйняту для зони Лісостепу й Полісся технологію вирощування цієї культури.

Фенологічні спостереження, оцінку стійкості посівів до вилягання, зимостійкість, ураженість хворобами проводили за методикою [10]. Наростання вегетативної маси i нагромадження сухої речовини визначали в основні етапи органогенезу рослин тритикале шляхом відбору проб у двох несуміжних повтореннях із $1 \mathrm{~m}^{2}$ iз двох суміжних рядків. Облік щільності посівів, їх виживання за зимово-весняний період проводили на постійних ділянках (2 м² із варіанта). Площу листкової поверхні рослин визначали методом «висічок» за О. О. Ничипоровичем [11] і за допомогою прискореного способу [7]. Морфологічні дослідження виконували за методикою І. Г. Серебрякова [12] та Ф. М. Куперман [6], аналіз структури урожаю - за методикою Н. О. Майсуряна [8]. Кількісні параметри якісного складу зерна визначали методом корелятивної інфрачервоної спектроскопії у ближній ІЧ-області спектру за допомогою аналізатора NIR-4500. Генетичний потенціал і стійкість його реалізації оцінювали за методом Ебертхарта-Рассела [17] та методикою державного сортовипробування сільськогосподарських культур [10]. Математично-статистичну обробку даних здійснювали за О. Б. Доспєховим [4] із використанням комп'ютерних програм Statistica-5.5 та Excel-2003.

Результати досліджень. Сорт «Славетне»гексаплоїд, належить до різновидності eritroalbum. Колос щільний, білого забарвлення, остистий (остюки короткі й формуються по всій довжині колосу), веретеноподібний, довжиною 11-13 см, неламкий. Нижня колоскова луска 3 коротким зубцем й зовні без опушення. Стебло слабко виповнене, заввишки 100-115 см, без воскового нальоту, неламке, міцне, потовщене, стійке до вилягання, під колосом має характерне 
опушення. Зернівка велика, червоного кольору, пшеничного типу розвитку. За одночасної сівби повна стиглість зерна настає на 3-4 доби раніше, ніж у сорту «АД 3/5». Маса 1000 зерен становить 40-60 г, натура зерна - 760-780 г/л. Зерно не має зморшкуватості, вимолочуваність його добра та задовільна. Кущ потужний, дещо розлогий, листкова пластинка коротка й вузька, піхва листка без воскового нальоту. Рослини тритикале сорту «Славетне» відрізняються від інших сортів слабким розвитком наземної вегетативної маси восени і більш пізнім початком активного відростання навесні, що й зумовлює їх високу зимо- та морозостійкість (9 балів). Інтенсивний розвиток рослин розпочинається за 7 діб до настання фази трубкування і за 7 діб наздоганяє сорти «АД 3/5», «АД 256», «АДМ 11». Посухостійкість цього екотипу висока (9 балів). Для «Славетне» невластива залежність між тривалістю періоду яровизації та морозостійкістю.

Середньобагаторічна (2004-2011рp.) урожайність зерна сорту «Славетне» в умовах перехідної зони Лісостеп-Полісся (Носівській СДС ICГМіАПВ НААН) складає 6,7 т/га, що на 1,2 та 0,5 т/га перевищує урожайність сортів АД $3 / 5$ i АД 256. За результатами виробничих випробувань цей сорт в умовах Харківської області формує 9,3, Сумської - 8,5 т/га, Київської - 8,1 т/га, Черкаської- 6,3 т/га, Житомирської обл. 3,8 т/га. У центральній частині Лісостепу (Київська обл., Фастівський, Таращанський, Білоцер- ківський, Сквирський р-ни) урожайність сорту «Славетне» істотно залежить від строків сівби. За норми висіву 5 млн шт./га та сівби 15 вересня він формує урожайність зерна 6,2 т/га, 25 вересня - 7,4 т/га, 05 жовтня - 7,0 т/га, 15 жовтня 6,1 т/га та 25 жовтня $-4,5$ т/га (рис. 1 ).

Дослідження біометричних параметрів рослин дали підставу стверджувати, що, порівняно 3 сортами АД 256, АД $3 / 5$, посіви сорту «Славетне» слабко реагують на тривалість світлового дня, не переростають до припинення вегетації восени та повільно розвиваються на початку вегетації навесні. Це, в свою чергу, спричиняє менш інтенсивне ураження посівів збудниками хвороб, шкідниками, більш збалансоване використання зимово-весняної вологи та поживних речовин упродовж весняної вегетації. Отже, зазначені особливості сорту «Славетне» зумовлюють формування високих показників урожайності його зерна.

Виявилося, що в умовах центральної частини Лісостепу оптимальним строком сівби сорту «Славетне» є 20-25 вересня. В цей період зазвичай випадають дощі, середньодобова температура повітря становить $9-14{ }^{\circ} \mathrm{C}$, що забезпечує сприятливі умови для посівів, у зв'язку з чим первинні зародкові корінці на 1,2-1,3 см довші, ïx на 1-2 шт. більше порівняно з посівами за пізніх строків сівби; з часом формується два вторинних стеблових кореня, загальна кількість

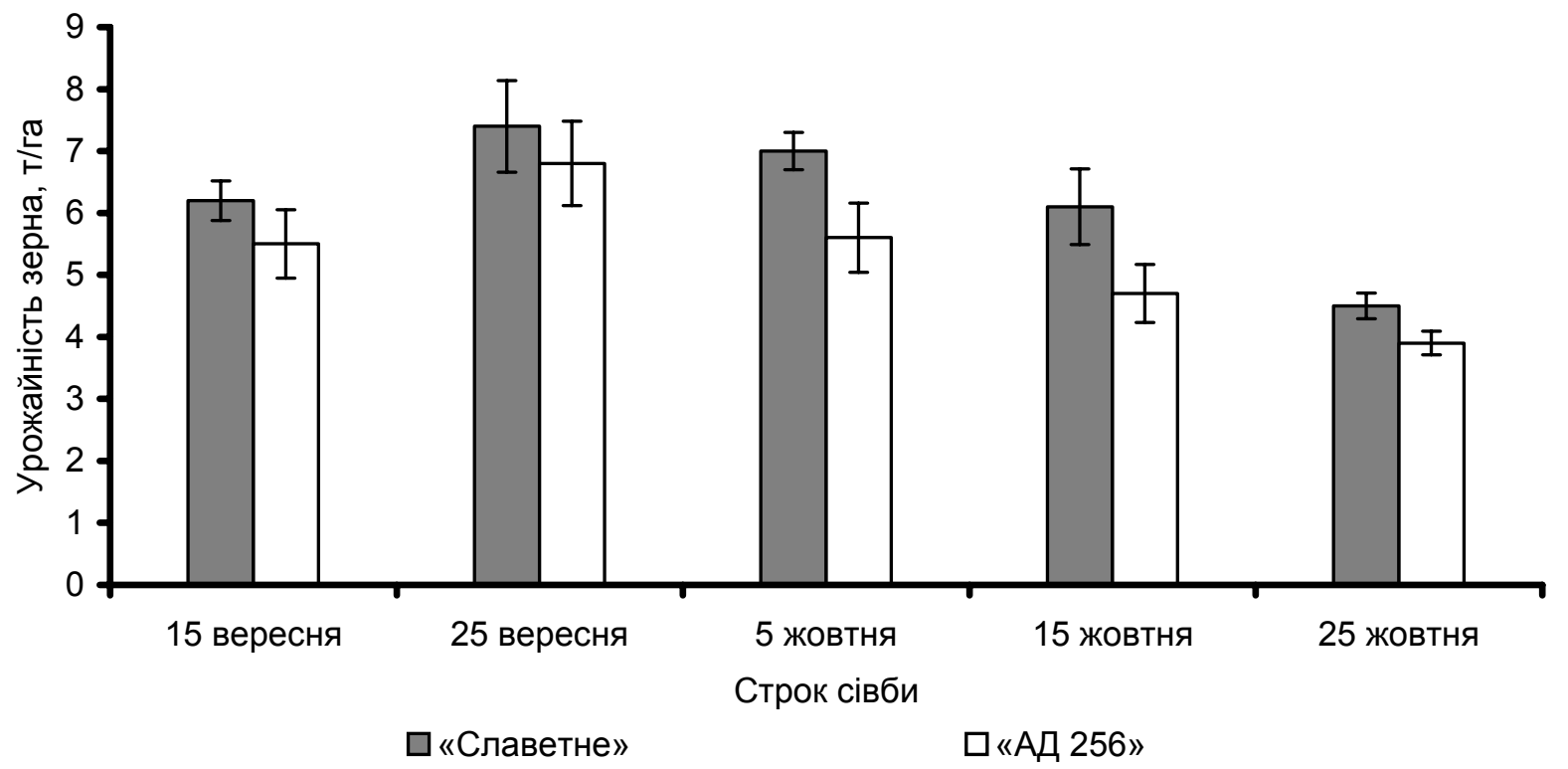

Рис. 1. Урожайність тритикале озимого залежно від строків сівби (середнє за 2007-2011 рр., ННДЦ БНАУ) 
стебел досягає 4 шт.; від кількості вторинних стеблових коренів істотно $(\mathrm{p}=0,05)$ залежить загальна кількість стебел ( $\mathrm{r}=0,8, \mathrm{p}=0,05 ;$ рис. 2). Рослини тритикале до зими встигають сформувати 2-3 стебла й 4-6 листочків на головному з них і досягти висоти близько 10 сантиметрів. За сівби 57 вересня близько $11 \%$ посівів випадає, за сівби 20-25 вересня - 1,5-4,5\%, 5-10 жовтня - близько $20 \%$. Окрім того, посіви «Славетне» ефективніше використовують запаси зимової вологи, що забезпечує сприятливі умови для утворення зачаткового колоса, колоскових горбочків весною та формування продуктивного колоса.

За сівби 5-10 жовтня розвиток посівів «Славетне» запізнюється на 7 діб, сходи з'являються на 14-у добу, фаза кущення проходить більш сповільнено, фаза виходу в трубку настає в другій декаді травня, проте настання фаз молочної та воскової стиглості відбувається майже одночасно, порівняно $з$ сортом «АД 256», хоча тривалість вегетаційного періоду у цих сортів однакова.

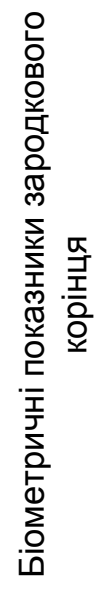

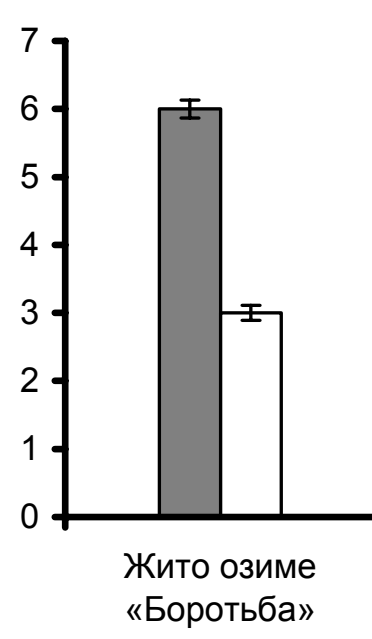

Кількість корінців, шт.

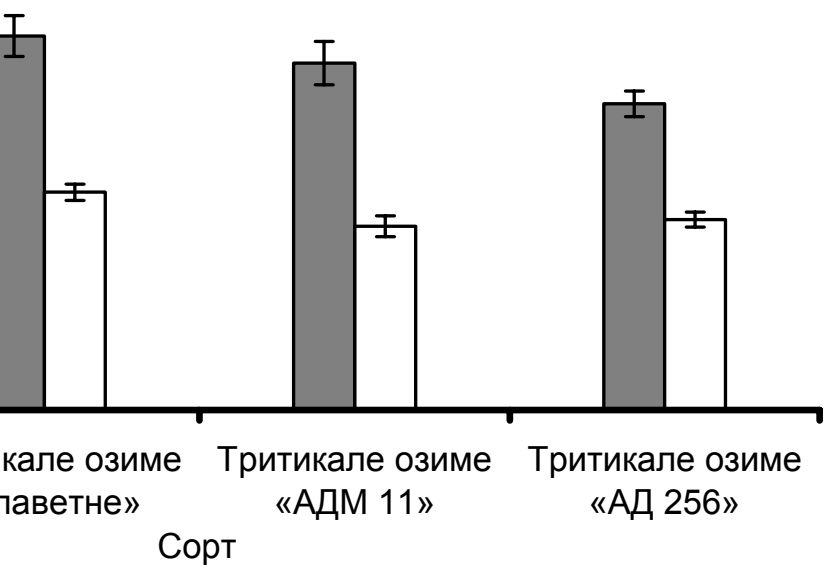

口Довжина корінців, см

Рис. 2. Біометричні параметри зародкового корінця залежно від виду та сорту (середнє за 2007-2011 рр., ННДЦ Білоцерківського НАУ)

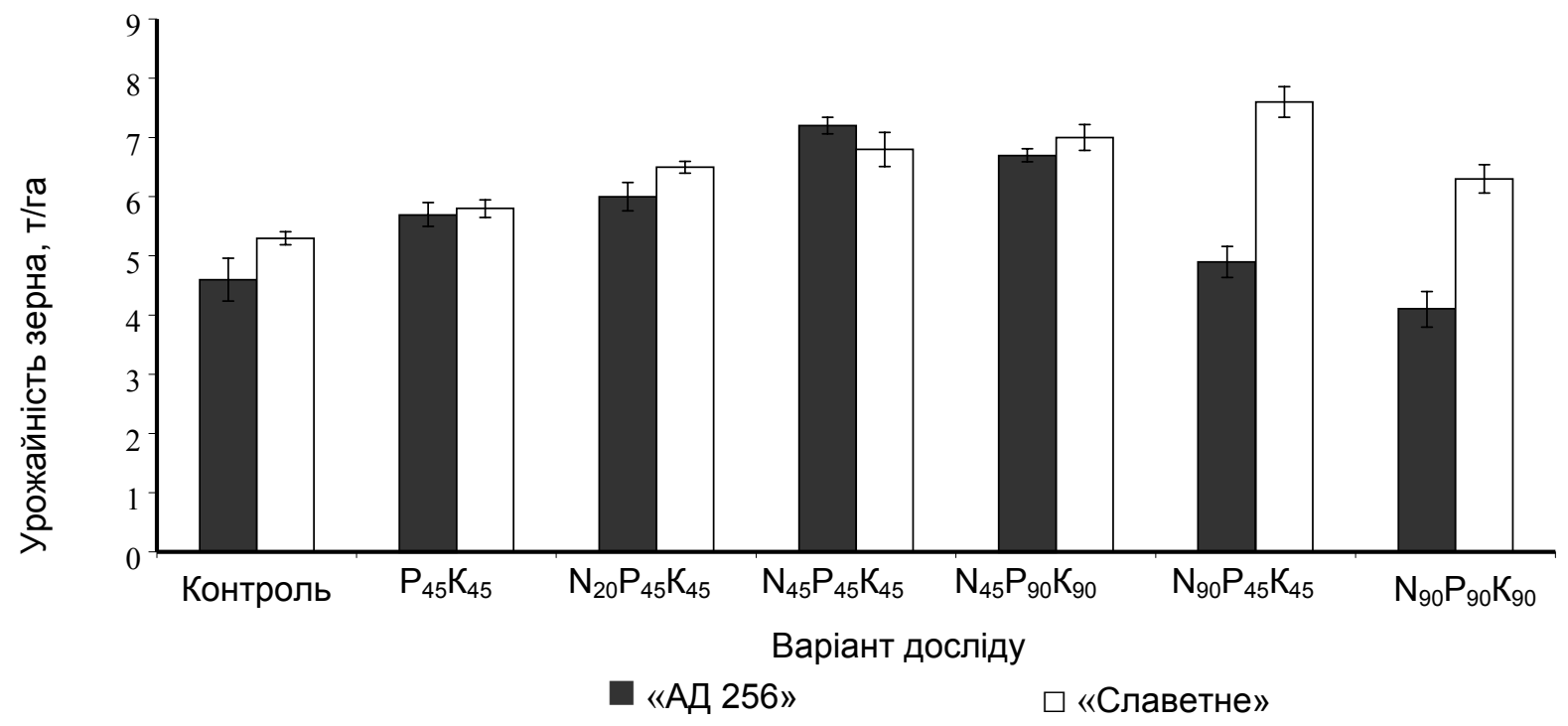

Рис. 3. Урожайність зерна тритикале озимого залежсно від сорту й доз мінеральних добрив (середнс за 2007-2011 рр., ННДЦ Білоцерківського НАУ) 
За оптимальних строків сівби (20-25 вересня), норми висіву (5 млн/га) та фону мінеральних добрив $\mathrm{N}_{20+25} \mathrm{P}_{90} \mathrm{~K}_{90}$ сорт «Славетне» у виробничих посівах дає урожайність зерна 7-8 т/га (рис. 3). Фосфорно-калійні добрива потрібно вносити під основний обробіток грунту, перше азотне підживлення сходів - у період формування колосу (закінчення 3-го та початок 4-го етапу) у дозі $\mathrm{N}_{20}$ (дозу азотних добрив можна збільшувати до $\mathrm{N}_{40}$, якщо щільність продуктивного стеблостою $150-200$ шт./ $\mathbf{M}^{2}$ ); друге підживлення азотними добривами в дозі $\mathrm{N}_{20-25}-\mathrm{y}$ період трубкування (це сприяє збільшенню кількості колосків у колосі, зерен із колоса, вирівнюванню стеблостою, пригніченню бур'янів посівами, зумовлює підвищення стійкості рослин до шкідників і хвороб). Для формування насінницьких посівів доцільною є норма висіву 4-4,5 млн/га, за умов низької родючості грунтів, незадовільних попередників, пізніх строків сівби - 6-6,5 млн/га. Подібні результати одержані й іншими дослідниками $[1,2,5]$.

За результатами багаторічних досліджень (2000-2011 рр.) сорту «Славетне» надано оцінку за генетиповим потенціалом і стабільністю реалізації його якостей. За урожайністю генотипо- вий ефект (Еi) сорту «Славетне» становить 0,16 (2 ранг) і ступінь пластичності (Ri) 0,26 (1 ранг), сорту «АД 256»- -0,17 (ранг 2) та -0,26 (ранг 1) відповідно. Обидва сорти за стійкістю до борошнистої роси та ступенем пластичності віднесено до першого рангу, за генотиповим ефектом до другого рангу. Неоднорідність умов екотопів $\epsilon$ вагомим фактором щодо урожайності зерна, варіабельність (V) якої становить 6,5-13,7 \%; гомеостатичність (Hom) - 5,1-12,4; розмах коливання (R) - 11-18. В умовах Житомирського Полісся на дерново-середньопідзолистому супіщаному грунті середня урожайність зерна сорту «Славетне» становила 3,9 т/га; у Чернігівському Поліссі на дерново-підзолистому супіщаному легкосуглинковому грунті - 4,5 т/га; у перехідній зоні Полісся-Лісостеп на чорноземі вилугуваному малогумусному легкосуглинковому - 8,5 т/га; в центральній частині Лісостепу на чорноземі глибокому середньосуглинковому - 6,2 й чорноземі типовому малогумусному легкосуглинковому - 7,7 т/га. Найменша істотна різниця за умов конкретної погодно-кліматичної та грунтової провінції складала, відповідно, 0,$4 ; 0,9 ; 1,1$; 0,5 та 0,3 т/га за рівня значущості $\mathrm{p}<0,05$ (рис. 4).

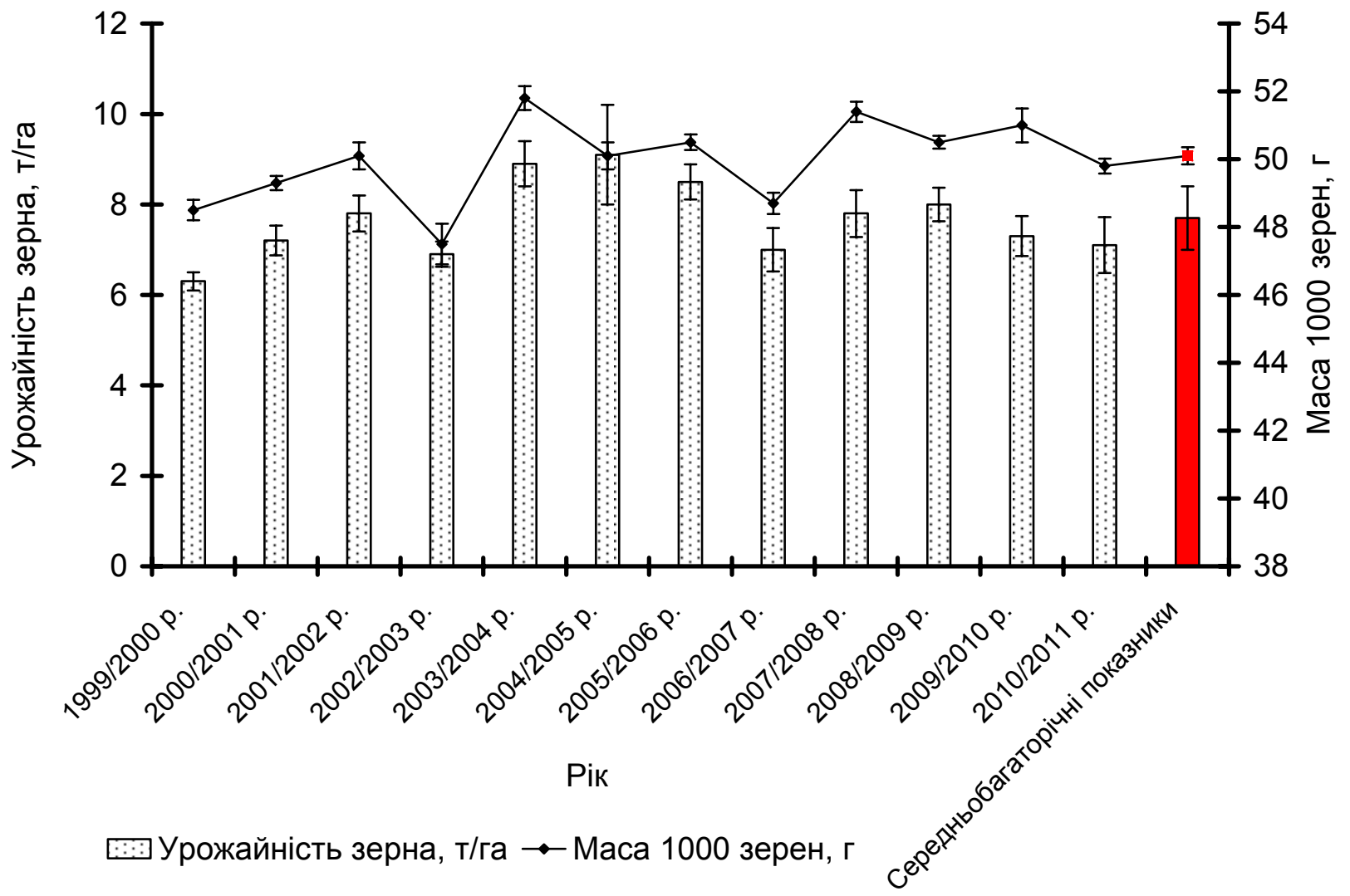

Рис. 4. Урожайність зерна тритикале озимого сорту «Славетне» за роками 


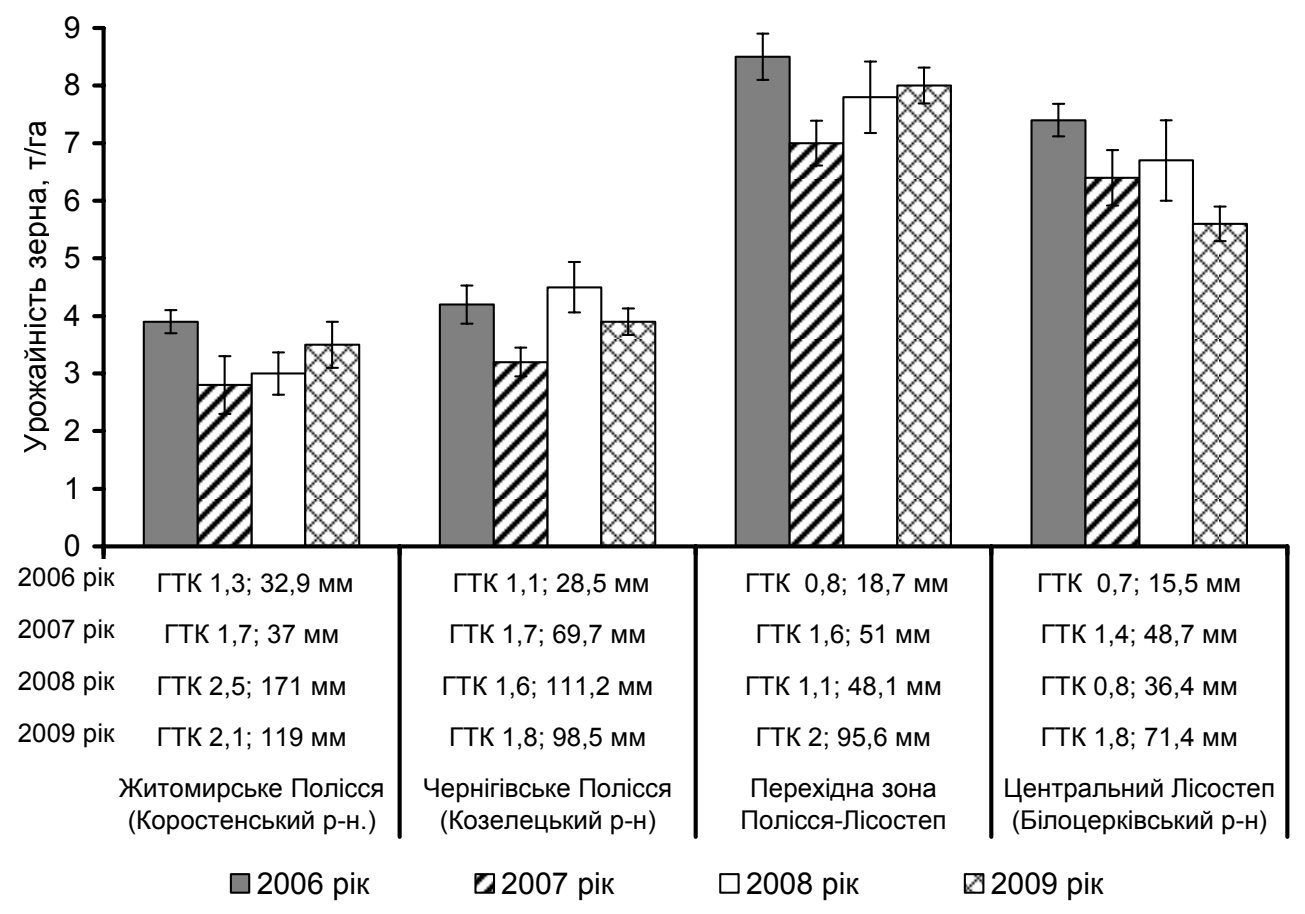

Рис. 5. Урожайність зерна тритикале озимого сорту "Славетне» залежно від гідротермічних умов за роками (ГТК та сума опадів упродовж X-ХII етапів органогенезу)

В умовах перехідної зони Лісостеп-Полісся та центрального Лісостепу в період X-XII етапів органогенезу тритикале «Славетне» значення ГТК коливалися в межах 0,8-1,1. Це забезпечує формування високої урожайності та якості зерна (вміст білка - 12,5-13,3\%). За значення ГТК 0,5, що відмічено в 2002, 2007 рр., коли гідротермічні умови були іншими, спостерігалася протилежна тенденція, порівняно 3 2003-2006 і 20082011 рр.: урожайність зерна була меншою, а вміст білка в зерні- більшим (13,5-13,8, за $\mathrm{p} \geq 0,05)$; за ГТК понад 1,3-1,4 (2000, 2001 pp.) навпаки: вміст білка в зерні зменшувався (рис. 5).

Відомо, що тритикале характеризується гетерогенністю. Ця властивість пшенично-житніх амфідиплоїдів дає можливість у посіві конкретного сорту відбирати «сестринські» лінії за комплексом бажаних якостей для подальшої селекціï. У зв'язку з цим, за жорстких умов ( $\mathrm{t}$ повітря -27-34 ${ }^{\circ} \mathrm{C}$ ) зими 2011-2012 pр. на спеціальному фоні (h снігового покриву 4-5 см) 3 сорту «Славетне» відібрано більш морозостійку лінію «Славетне покращене».

Висновки. В умовах східного та центрального Полісся, північного та центрального Лісостепу України сорт тритикале озимого «Славетне» характеризується як високопродуктивний, високоврожайний, стійкий до характерних регіону негативних біотичних i абіотичних факторів.
За умов нормальної вологозабезпеченості грунту оптимальними строками сівби для сорту «Славетне» є 15-20 вересня, норма висіву $-4,5-5$ млн шт./га. В умовах Житомирського Полісся на дерново-середньопідзолистому супіщаному грунті середня урожайність зерна сорту «Славетне» становить 3,9 т/га; у Чернігівському Поліссі на дерново-підзолистому супіщаному легкосуглинковому грунті - 4,5 т/га; у перехідній зоні ПоліссяЛісостеп на чорноземі вилугуваному малогумусному легкосуглинковому - 8,5 т/га; у центральній частині Лісостепу на чорноземі глибокому середньосуглинковому - 6,2 й чорноземі типовому малогумусному легкосуглинковому - 7,7 т/га. Найменша істотна різниця за умов конкретної погодно-кліматичної та грунтової провінції становить, відповідно, 0,$4 ; 0,9 ; 1,1 ; 0,5$ та 0,3 т/га за рівня значущості $\mathrm{p}<0,05$. За урожайністю генотиповий ефект (Еi) сорту «Славетне» становить 0,16 (2 ранг), ступінь пластичності (Ri) 0,26 (1 ранг), сорту «АД 256»- -0,17 (за ранговою оцінкою - ранг 2), ступінь пластичності (Ri) $-0,26$ (ранг 1). Обидва сорти за стійкістю до борошнистої роси та ступенем пластичності віднесено до першого рангу, за генотиповим ефектом - до другого рангу.

Для забезпечення оптимальних цільових параметрів урожаю зерна в умовах північного та центрального Лісостепу на посівах «Славетне» доцільно вносити мінеральні добрива із розра- 
хунку $\mathrm{N}_{20+25} \mathrm{P}_{90} \mathrm{~K}_{90}$ за норми висіву 4,5 млн шт./га, в умовах східного та центрального Полісся - $\mathrm{N}_{30+30} \mathrm{P}_{120} \mathrm{~K}_{120}$ i 5 млн шт./га відповідно.

Доволі висока екологічна стійкість тритикале озимого «Славетне» до негативних екологічних факторів, повільний розвиток на початку онтогенезу та вчасне його завершення сприяють

\section{БІБЛІОГРАФІЯ}

1. Білітюк А. П. Тритикале в Україні / А. П. Білітюк, В. С. Гірко, С. М. Каленська, М. І. Андрушків; за ред. А. П. Білітюка. - К., 2004. - 376 с.

2. Білітюк А. П. Агротехнологічні основи вирощування тритикале в Україні / А. П. Білітюк // Агроном: науково-виробничий журнал- К. : ТОВ «Агромедіа», 2005. - № 3. - С. 26-30.

3. Вожегова P. А. Устойчивость сортов озимой пшеницы к грибным заболеваниям / Р. А. Вожегова // Вісник аграрної науки. - 1998. - № 6. C. 25-26.

4. Доспехов Б. А. Методика полевого опыта / Б. А. Доспехов. - М. : Агропромиздат, 1985.$351 \mathrm{c}$.

5. Ковтуненко В. Я. Возделывание тритикале укрепление кормовой базы животноводства на Кубани / В. Я. Ковтуненко, В. Б. Тимофеев, Б. А. Гольдварг [и др.] // Тр. Кубанского государственного аграрного университета / КубГАУ. - 2008. - Вып. № 4 (13). - С. 83-89.

6. Куперман Ф. М. Морфофизиология растений. Морфофизиологический анализ этапов органогенеза различных жизненных форм покрытосемянных растений: учеб. пособие для биол. спец. ун-тов / Ф. М. Куперман. - 3-е изд., перераб. и доп. - М. : Высш. школа, 1977. - 288 с.

7. Лавриненко Ю. А. Ускоренный способ определения площади поверхности листа / Ю. А. Лавриненко, А. Д. Жужа, А. П. Орлюк // Селекция и семеноводство. - 10. - 1981. - С. 12-13.

8. Майсурян Н. А. Практикум по растениеводству / Н. А. Майсурян. - Изд. 6-е. - М. : Колос, 1970. - $446 \mathrm{c}$.

9. Медведев A. М. О недостатках и преимуществах тритикале в сравнении с другими зерновыми растениями / А. М. Медведев, Л. М. Медведева // кращому протистоянню рослин шкідникам, збудникам хвороб, ефективнішому використанню ними зимово-весняної вологи та поживних речовин грунту.

На базі сорту «Славетне» шляхом індивідуального відбору створено більш морозостійку лінію «Славетне покращене».

Тритикале России: материалы заседания секции тритикале. - Ростов-на-Дону: РАСХН, 2008.T. 67. - C. $140-146$.

10. Методика державного сортовипробування сільськогосподарських культур (зернові, круп'яні та зернобобові культури); Під ред. В. В. Волкодава. - К., 2002. - Вип. 2. - С. 64-66.

11. Ничипорович A. А. Задачи по изучению фотосинтетической деятельности растений как фактора продуктивности / А. А. Ничипорович. - М., 1966. - C. 7-50.

12. Серебряков И. Г. Морфология вегетативных органов высших растений / И. Г. Серебряков.М. : Сов. наука, 1952. - 391 с.

13. Технология производства и качество продовольственного зерна / Э. М. Мухаметов, М. А. Казанина и др. - Минск : Дизайн ПРО, 1996.$256 \mathrm{c}$.

14. Щипак Г. В. Селекція сортів озимої твердої пшениці і тритикале 3 підвищеними адаптивними і урожайними властивостями / Г. В. Щипак // Селекція польових культур. Зб. наук. праць до 100-річчя створення Інституту рослинництва ім. В. Я. Юр'єва УААН. - Х., 2008. - С. 42-88.

15. Щипак $Г$. В. Результаты селекции озимой тритикале на урожайность, зимостойкость и качество зерна / Г. В. Щипак, А. П. Петрова, Е. Н. Шевченко, В. Г. Щипак // Вісник ЦНЗ АПВ Харківської області. - 2010. - Вип. 9. - С. 179188.

16. FAO. 2010. FAOSTAT, FAO statistical databases - agriculture (available at http://apps.fao.org). 17. Eberhart A. Stability parameters for comparing varieties / A. Eberhart, W. Russell // Crop Science. - N 6. -1966 . - P. 36-40. 